\title{
Urban Expansion and the Dynamics of Farmers' Livelihoods: Evidence from Bamenda, Cameroon
}

\author{
Akhere Solange Gwan ${ }^{1}$ and Jude Ndzifon Kimengsi ${ }^{2,3, *(D)}$ \\ 1 Department of Geography and Planning, The University of Bamenda, Bambili 00237, Cameroon; \\ akheregwan@yahoo.com \\ 2 Faculty of Environmental Sciences, Technische Universität Dresden, 01737 Tharandt, Germany \\ 3 Department of Geography, The University of Bamenda, Bambili 00237, Cameroon \\ * Correspondence: jude_ndzifon.kimengsi@tu-dresden.de
}

Received: 12 June 2020; Accepted: 14 July 2020; Published: 18 July 2020

check for updates

\begin{abstract}
There is growing interest in the need to understand the link between urban expansion and farmers' livelihoods in most parts of sub-Saharan Africa (SSA), including Cameroon. This paper undertakes a qualitative investigation of the effects of urban expansion on farmers' livelihoods in Bamenda, a primate city in Cameroon. Taking into consideration two key areas-the Mankon-Bafut axis and the Nkwen Bambui axis—-this study analyzes the trends and effects of urban expansion on farmers' livelihoods with a view to identifying ways of making the process more beneficial to the farmers. Maps were used to determine the trend of urban expansion between 2000 and 2015. Twelve farmers drawn from the target sites were interviewed, while three focus group discussions were conducted. Thematic analysis was employed to analyze perceptions of the effects and coping strategies of farmers to urban expansion. Using the livelihoods approach, farmers' livelihoods repertoires and portfolios were analyzed for the periods before and after urban expansion. Between 2000 and 2015, the surface area for farmlands in Bamenda II and Bamenda III reduced from 3540 ha to 2100 ha and 2943 ha to 1389 ha, respectively. This was followed by a corresponding increase in the surface area for settlements from 2100 ha to 3540 ha in Bamenda II and from 1389 ha to 2943 ha in Bamenda III. The expansion process has affected farmers' income, farm sizes and farming types, natural capital, and their standards of living. Most of the farmers have employed coping measures to include the diversification of income opportunities, social networking, and agricultural intensification. Future efforts could target land use regulations to stem the uncontrolled rate of settlement expansion, intensive farming to increase productivity and processing to improve the value chain in a bid to increase income levels and provide long-term food self-sufficiency. This paper suggests further quantitative investigations to ground the current assertion.
\end{abstract}

Keywords: urban expansion; livelihoods; farming; assets; income; Bamenda

\section{Introduction}

Urban expansion (the extension of built-up areas or infrastructure in general from the city towards the rural areas) is one of the determinants of economic growth in most parts of sub-Saharan Africa (SSA); this partly explains why it is widely studied today [1]. Urban expansion is most rapid in the developing world where cities gain an average of about five million residents or inhabitants monthly [2]. Though rapid in SSA and other developing countries, it is a common phenomenon in almost all countries all over the world, albeit with varying degrees. The history of urban growth indicates that the urban areas on earth are the most dynamic, the trend is usually or most often from the urban towards the rural areas, which are characterized by less built-up areas, irrigation, and other 
water management systems [3]. This could indicate an attribute to the increasing adoption of the option of horizontal instead of vertical expansion and compact city development.

Between an urban and a rural area, there is a region of transition where the city's influence continues beyond the stipulated administrative boundaries and the rural area gradually adopts urban style and function. This area is "not a discrete area", but rather a diffuse territory identified by combinations of features and phenomena, generated largely by activities within the urban area proper. Reference [4] describes this region as an "uneasy phenomenon" because it has a mixture of attributes that are difficult to separate. Most often, the outward expansion of cities towards the periphery creates some ambiguity and makes a clear-cut demarcation of urban from rural environments seemingly difficult [4]. However, it is observed that between the limit of what constitutes urban and rural, there is a region of transition which is known as the peri-urban environment. Although the term peri-urban is usually used to convey the overlapping of rural and urban areas, it is seemingly difficult to delimit and define it. The definitional problem lies mainly in the difficulty of delimiting the spatial extent of this dynamic region, and in the interpretation of the notion of transition [5]. This transitional element can be measured by a wide variety of criteria that are used to distinguish rural from urban, including population density, the presence or absence of built-up areas and infrastructural characteristics, administrative boundaries, and the predominant economic activities that take place [4]. It would thus appear that some confusion exists not only with respect to a physical definition of the peri-urban region, but also in the criteria that are used to measure and delimit this dynamic region. Nevertheless, over the years, numerous definitions of the term peri-urban have emerged, most of which broadly agree that peri-urban regions are areas which are generally rural in character, but are under the influence of urban factors or processes [6,7]. References [8,9] refer to the region as, "the periphery of urban agglomeration where economic and social activities are directly affected by the presence and expansion of the city." Reference [9] describes this (rural-urban fringe) region as a hybrid of both the influences of the rural areas and the urban areas. The author argues that this phenomenon is best thought of as a step in the hierarchy of development between the rural and the urban area. The city or the town develops in a circular manner from the center towards the edges, and as such, what is presently a fringe eventually becomes incorporated into the city as suburban. This is common in SSA, including Cameroon.

The Cameroonian urban landscape is not spared in the current wave of rapid and uncontrolled urban growth which extends at the fringes $[10,11]$. Cases in point could be observed for Douala Bonaberi which has evidently spread to Bikoko. Yaounde today has grown significantly with neighborhoods such as Emombo, Simbock, and Nkolbisson witnessing dramatic change. The case of the Bamenda, the primate city of the North-West Region, is also evident as this process of urban expansion seemingly affects the livelihoods of farmers. While research efforts have been directed towards analyzing the environmental implications of urban expansion $[7,12,13]$, insufficient research attention has been paid on the effect of urban expansion on the livelihoods of farmers especially in the case of Bamenda. Therefore, an important aspect which seems to have eluded urban geographical literature, or better still remains insufficient in the context of Bamenda, concerns scientific perspectives on the effect of urban expansion on farmers' livelihoods. This is especially so as existing literature centered on the effect of urbanization on the Bamenda wetland environment [14-16].

In the case of Bamenda, the process of urban expansion has seemingly affected the livelihoods of farmers who have, over the years, been involved in different types of farming ranging from shifting cultivation, bush fallowing, and animal/cattle farming. Hence, the livelihood of people in this area is based on agriculture/farming. This is discernable in two locations under consideration: the Mankon-Bafut axis and the Nkwen Bambui axis of the town. The effect of the urban expansion process could be observed through a progressive reduction in the size of farmland and a change in the farming practices, mirrored through changes in livelihood repertoire and portfolio of farmers. Such changes equally vary for the Mankon-Bafut axis and the Nkwen Bambui axis. This paper adopts an exploratory approach, to unbundle the effects of urban expansion on farmers' livelihoods in Bamenda. 
The results are pertinent for a case-based scientific appreciation of the status and livelihoods of farmers in the face of urban expansion, and to inform urban development policy in Cameroon and similar context of SSA.

\section{Analytical Lens}

The livelihoods approach (LA) has been an "idea in good currency" in scientific and development literature since the late 1990s [17,18]. The 1997 white paper on international development called for an emphasis on sustainable livelihoods through the elimination of poverty and the encouragement of economic growth which benefits the poor. These will create sustainable livelihoods for poor people, promote human development, and conserve the environment [19]. It was typically applied in poorer countries as part of a planning phase for policy intervention. In that sense, the LA represented an analysis of peoples' current livelihood and what is needed for an "enhancement" and was useful in avoiding the inappropriate interventions critiqued by the post-developmentalists. This concept, therefore, fits in the context of the study since on the one hand, it explains the scientific basis for farmers' livelihoods, access to livelihood opportunities, and vulnerability (mainly the loss of agricultural land to urban expansion) which influence livelihood outcomes. On the other hand, it also serves as a practical tool for livelihood enhancement and diversification. Drawing inspiration from the LA, we developed a simplified analytical lens that depicts the streams of actions, events, and processes in a network (Figure 1).

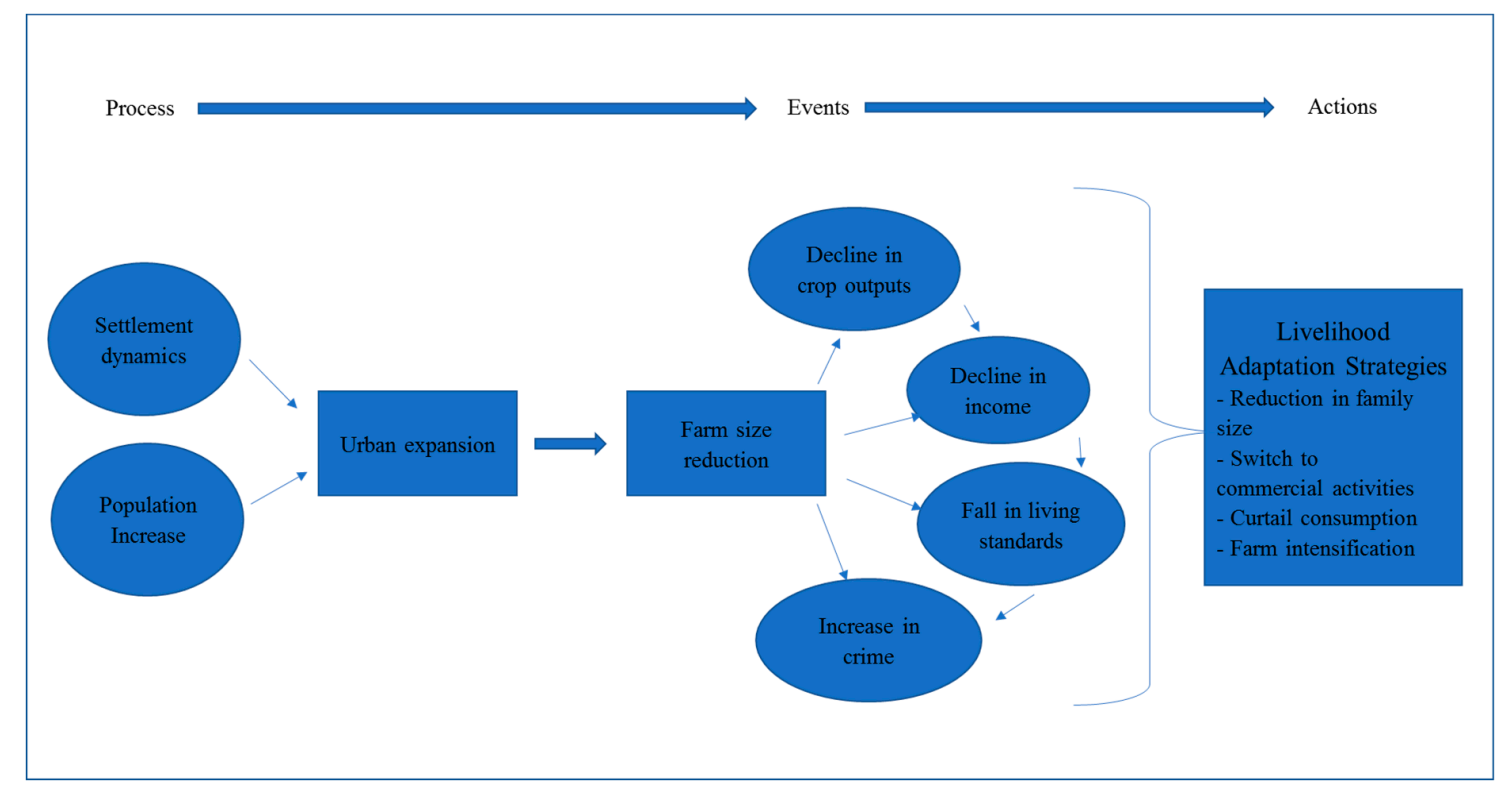

Figure 1. A network analysis of urban expansion, effect on farmers' livelihoods, and adaptation strategies (authors' conception).

We employed the use of networks showing nodes or points connected by links or lines that display streams of participant actions, events, and processes. Considering that the research assumes a case-oriented approach, networks lend themselves sufficient credence to create a "plot" of events over time, as well as to demonstrate complex interrelationships between variables [20]. In this regard, network was used to show the links between processes (urban expansion through population increase and settlement dynamics) which lead to events (farm size reduction, reduction in crop output and incomes, fall in living standards, and increasing crime). This necessitated actions (adaptation strategies) such as a reduction in family size, a switch to other commercial activities, curtailment of consumption, and farm intensification. 


\section{Materials and Methods}

\subsection{Study Area}

This research was conducted in Bamenda, a primate city in the North-West region of Cameroon. Bamenda city is the capital of the North-West Region (NWR) of Cameroon (Figure 2). It is sub-divided into three zones which are Bamenda I, II, and III. Each of these zones has a council, independent of the other. However, they are all answerable to the Bamenda City Council (BCC). The choice of Bamenda due to demographic, historical, and politico-administrative reasons. Demographically, Bamenda is considered as one of the most urbanized towns in Cameroon, making it a relevant case to explore the livelihood dynamics of farmers in the face of continued urban expansion. Historically, Bamenda is one of the towns in Cameroon that witnessed early colonial influence under the German and later British rule. These influences meant that it stood as one of the main towns in the Former West Cameroon. Bamenda today plays the role of a primate city in the North-West Region of Cameroon given its multiple roles as a hub of secondary and higher education and its administrative role as the regional headquarters of the North-West Region and the divisional headquarters of Mezam Division. Such administrative and social attractions come with urban multiplication or growth which in turn affects the livelihoods of inhabitants (especially farmers) at the urban fringes.

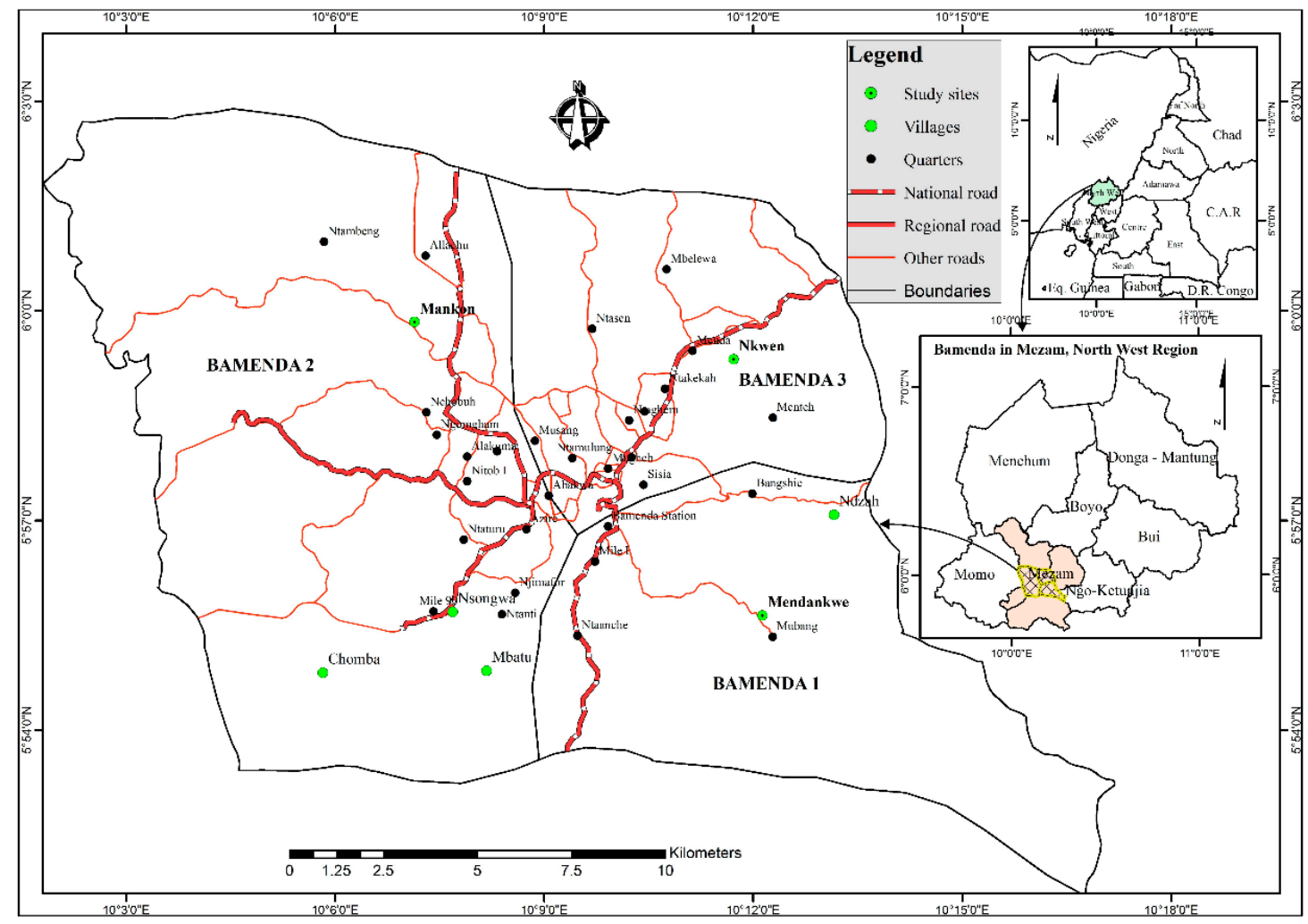

Figure 2. Map of Bamenda city showing the municipalities. Source: Compiled from the National Institute of Cartography and the Bamenda City Council.

It should be noted that agriculture is the source of livelihood for approximately more than $80 \%$ of the population at the urban fringes. From a political standpoint, the choice of Bamenda is justified by the fact that this town gave birth to two main political parties in Cameroon: the Cameroon's People Democratic Movement (CPDM), which is the leading political party in Cameroon, and the Social Democratic Front (SDF), which is the main opposition party in the country. Such sensitive issues as the colonization of lands and their effects on livelihoods form a major debate platform for these two parties. Furthermore, Bamenda is one of the hotspots of separatist movements, especially the 
Southern Cameroon National Council (SCNC) activists. This group is advocating for the separation of the English-speaking part of Cameroon from the French-speaking part. They equally capitalize on some of the frustrations of peasant farmers linked to land grabbing to lobby for more of a following. With mounting pressure and persistent clashes over access to land, fueled by urban expansion, studies of this nature are useful in a politically sensitive environment where access to land and livelihood sustenance by farmers could spark up violence if not well managed.

Based on background experiences and knowledge on the nature of Bamenda, interviews were conducted with traditional rulers, municipal authorities, and the Divisional Delegates of State Property and Land Tenure as well as Urban Development and Housing. These discussions gave room for a proper orientation on the possible sites that should be considered for the study. The specific fringes chosen were the Nkwen-Bambui axis, which is located North East of Bamenda (beginning from Mile 3 to Mile 8 Nkwen), and the Mankon-Bafut axis, found at the North-West of Bamenda (beginning from Ntarinkon to Mile 8 Mankon). These sections are considered the urban fringes since they do not fully exhibit characteristics of urban life as is observed in the inner city. Even though these two were selected, they are not the only frontiers where rural and urban areas meet in Bamenda. However, they (Nkwen and Mankon) represent the areas with greater expansion. Expansion towards the east is very slow due to the hilly nature of the area. They were also chosen because the effects of urban expansion in these areas in terms of colonization of rural lands are glaring. In addition, they play host to a series of farming groups, common initiative groups, and key informants (traditional rulers and quarter heads). With these in mind, we identified target communities for focus group discussions (FGDs).

\subsection{Data Collection}

Qualitative research seeks to answer questions, make use of predefined sets of procedures, collect data or evidence, and produce findings that are not determined in advance and are applicable beyond the immediate boundaries of the study. Through this method, the researcher seeks to understand behavioral conditions through the actor's perspective; this helps to explain both the process and outcome of a phenomenon through complete observation, reconstruction, and analysis of the cases under investigation [21]. The qualitative research methods used to carry out the study included interviews and focused group discussions. The target population of this research work included farmers in the Mankon-Bafut axis and the Nkwen-Bambui axis. An interview guide was prepared containing 10 relevant questions which were semi-structured and addressed to respondents. A focus group discussion guide was equally designed consisting of six open-ended questions. These questions were raised on a number of issues to include farmer's perception of urban expansion in Bamenda, the livelihood repertoire and portfolio of farmers before and after urban expansion, the effects of urban expansion, attempts made by farmers to address the issue, and their livelihood adaptation strategies. The design and validation of the research instruments for this study were completed between March and May 2016.

The data collection process began with a two-day reconnaissance survey and observation of the research area. The survey was done to provide an opportunity for full acquaintance with the realities of urban expansion and its effect on agricultural activities. This was followed by a pretest of the research instruments with farmers $(\mathrm{N}=5)$ in Akum, an adjacent semi-urbanized community to Bamenda. The reconnaissance survey and pretest led to the identification of suitable study sites and the refinement of the research instruments, respectively. The chosen study sites were the Mankon-Bafut axis (Bamenda II municipality) and the Nkwen-Bambui axis (Bamenda III municipality). The interviewees included those within 1 to $3 \mathrm{~km}$ away from the city, northward and northeastward, respectively. Each of these two regions had six interviewees, three men and three women. The respondents included those who have an alternative source of income and those who do not but rely only on farming. Hence, a total of 12 individual farmers were interviewed (Figure 3). Getting to the individual informants was done using the snowball method in the case where the required numbers of interviewees were not easily met and based on recommendations from other interviewees. Interviews with these farmers aimed at 
obtaining information concerning their previous and current situation (at the time of the interview), what they perceived, how badly they were affected, and changes in their livelihood pattern. In addition, they explored how expansion has affected methods of farming as well as what adaptive and coping strategies they were using, whether the authorities met their expectations, and whether they were being compensated or not. In addition to the farmers, quarter heads and municipal authorities were also interviewed.

A total of 12 farmers were interviewed (six men and six women). Most of the interviews took place in the comfort of their homes, except in a few cases where interviews were conducted in marketplaces, palm wine bars, and in the farms. In addition, quarter heads, traditional authorities, and government authorities such as the Divisional Delegates of State Property and Land Tenure and Division Delegates of Urban Development and Housing were interviewed. After the in-depth interviews of 12 farmers, it was deduced that further interviews would only provide quite similar responses. Therefore, to address issues of data saturation [22], it was judged to end with the 12 in-depth interviews, and to further triangulate the data through focus group discussions. A total of three focus group discussions were held: one from Nkwen and the other two from Mankon. These focus groups consisted of both men and women with nine participants in one and six in others. The focus group discussions were done after the interview process. Each session lasted between $1 \mathrm{~h} 30 \mathrm{~min}$ and $2 \mathrm{~h}$.

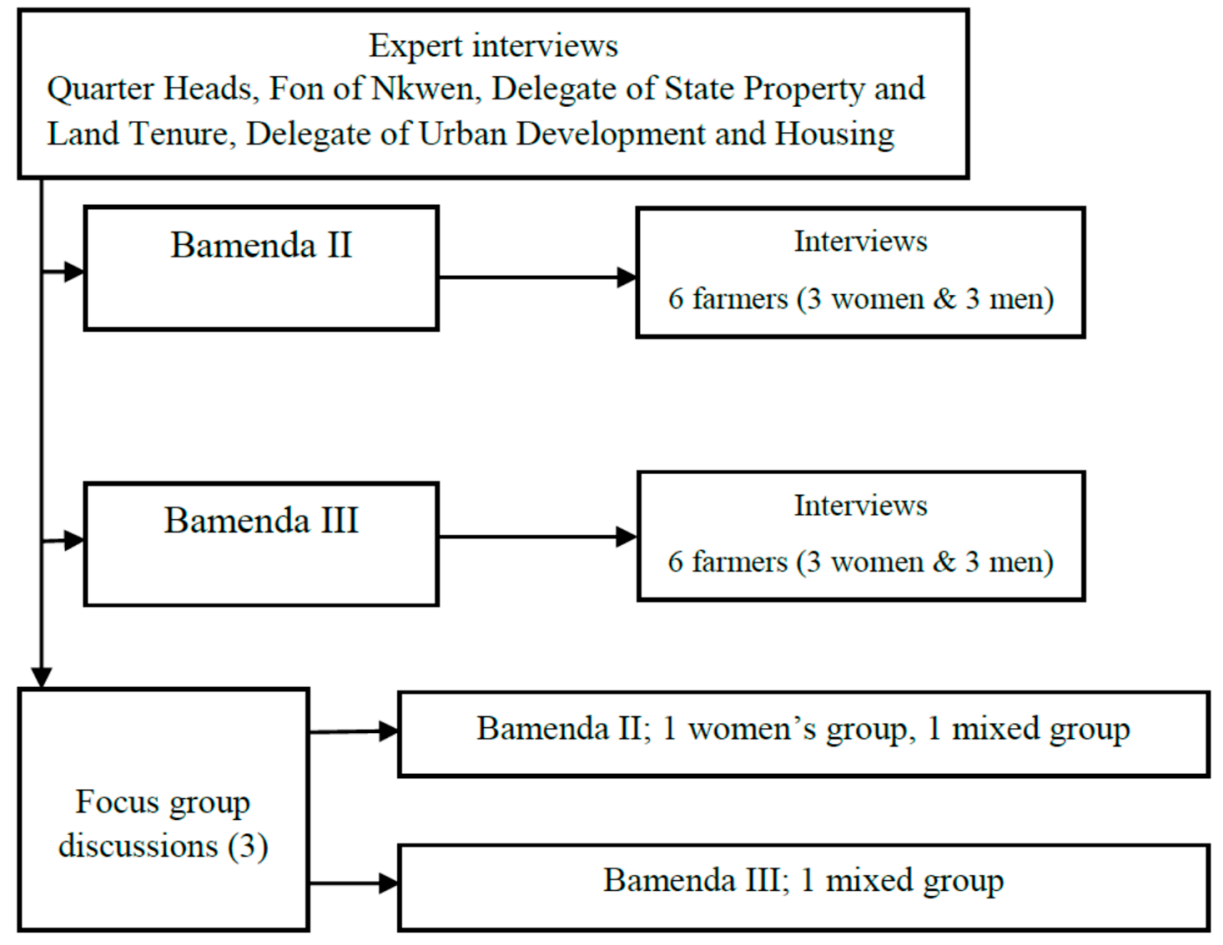

Figure 3. Data collection chart.

It was easy to organize the respondents since the aspect of trust was developed with the help of a gatekeeper. The motive behind the research was explained to the participants and we sought their consent before recording the information. We also assured participants that their responses will be treated as confidential. Field notes and voice recorders were used to record the data. The data obtained were transcribed and coded. Based on the coded data, we summarized this information in the narratives presented in the results section. Further complementary evidence was generated through shadowing, in which the lead author followed the farmers daily, to understand and appreciate their lifestyles. This information was useful in assessing the livelihood adaptive measures of the farmers. All of the informants selected were between the ages of 30 to 50 years, they had lived in the area for at least 10 years, and they were considered to be experienced enough to share their views on the situation 
as it unfolded over the years. This condition was necessary because based on information from the Bamenda City Council and the Mezam Divisional Delegation of Urban Development and Housing, significant transformations have been witnessed in the Nkwen-Bambui axis and the Mankon-Bafut axis within the last 10 years. The data collection period ran from June to August 2016.

\subsection{Data Analysis}

This study was deductive in nature [23], as the research questions (framed along themes during analysis) were proposed prior to data collection. The themes were framed along the lines of the dynamics of urban expansion, urban expansion, and farmers' livelihood, livelihoods repertoire, and portfolio of farmers before and after urban expansion. Based on this, further details linked to farm sizes and distances covered to the farms, among others were also derived. These themes formed the basis for the analysis that was employed. Based on the interactions through interviews and FGDs, complemented by secondary sources, the researcher heavily employed the thematic analysis and narratives to examine the effect of urban expansion on the livelihoods of farmers and the adaptation strategies employed. This saw the transcription and examination of participants' diverse opinions. One of the key challenges observed for this method employed is the fact that it does not show in quantitative terms the perception of participants towards urban expansion and its effect. Furthermore, no simulation model was developed to project future developmental scenarios should urban expansion continue. In addition, direct quotes and extracts from field notes were used to explain some of the issues related to the loss of livelihoods of farmers due to urban expansion. The study relied on qualitative analytical tools to clearly analyze without eliminating or suppressing the views expressed through interviews and focus group discussions. Such an analytical strategy was chosen because it could clearly portray the intricacies associated with the question of farmers' perceptions of urban expansion and their livelihood choices in the face of limited agricultural assets (land).

\section{Results}

\subsection{The Dynamics of Urban Expansion in Bamenda}

The city of Bamenda has been experiencing high population growth and settlement expansion. The cases of Bamenda II and III are of importance in this study. Prior to 2015, precisely around the year 2000, the urban agglomeration of Bamenda II could be identified around neighborhoods such as Ntambang, Azire, Nintob I, Ngomgham, Alakuma, and Ntamulung (Figure 4). Evidence of urban expansion was limited during this period with little patches identified around Alabukam. However, by 2015, much of the Mankon-Bafut axis witnessed significant encroachment of urban settlements. Today, urban expansion has engulfed areas such as Nchobuh, Allachu, Ntambeng, and Ntamelon. Between 2000 and 2015, there was a reduction in the surface area for farmlands from 3540 ha to 2100 ha and a corresponding increase in the surface area for settlements from 2100 ha to 3540 ha. This ushered in a new wave of livelihood strategies adopted by farmers around the urban peripheries.

In the case of Bamenda III, limited urban expansion was witnessed until after 2000. Before this period, the urban agglomeration of Bamenda III could be identified around neighborhoods such as Mugheb, Bayelle, Ntaghem, Ntenefor, and Ntakekah. Evidence of urban expansion was limited during this period with little patches identified around Takem and Mambu. However, by 2015, much of the Nkwen-Bambui axis, which mainly constituted farmlands at the time, had witnessed significant encroachment of urban settlements. Today, urban expansion has engulfed areas such as Mile 4, Mile 5, Mile 6, Menda, and Nkwen Palace. These areas were generally characterized by farmlands prior to their colonization due to urban expansion (Figure 5). Between 2000 and 2015, the surface area for farmlands in Bamenda III reduced from 2943 ha to 1389 ha. This was followed by a corresponding increase in the surface area for settlements from 1389 ha to 2943 ha in Bamenda III. The expansion process has affected farmers' income, farm sizes and farming types, natural capital, and their standards of living. 


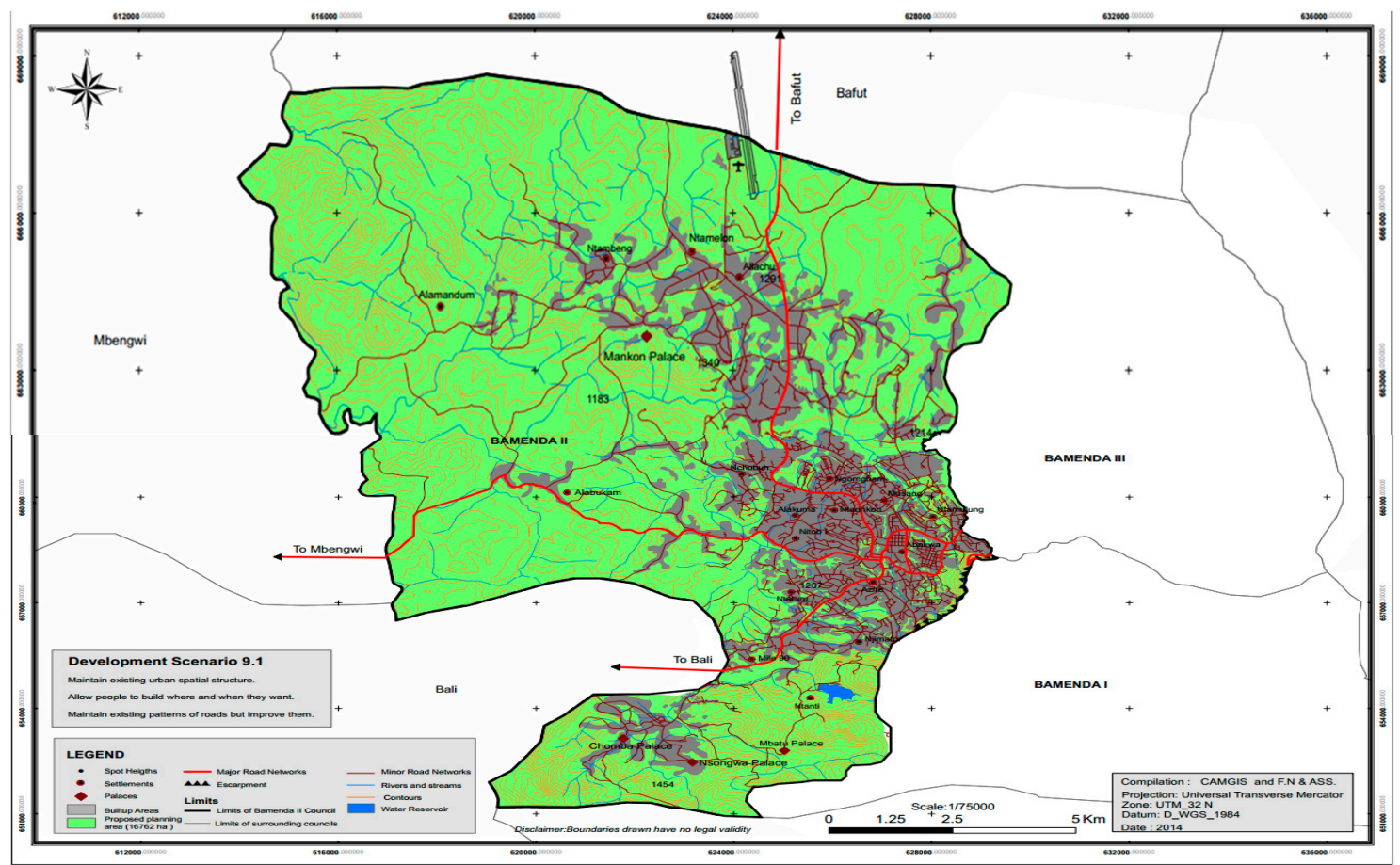

Figure 4. Urban expansion in Bamenda II (2015). Adapted from Bamenda II Council Map.

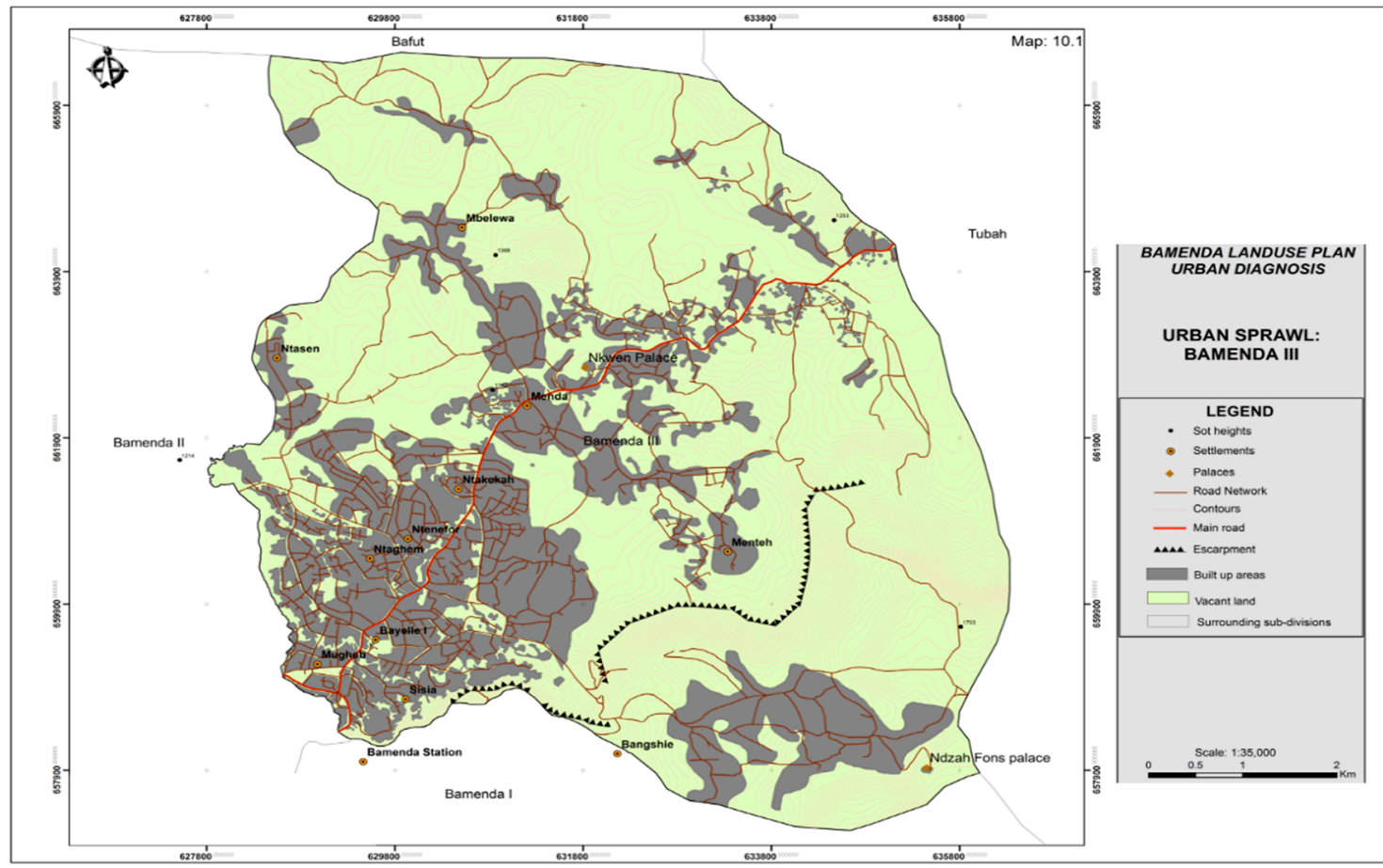

Figure 5. Urban expansion in Bamenda III by 2015. Adapted from Bamenda III Council.

\subsection{Urban Expansion and Farmers' Livelihood}

The process of urban expansion is usually hardly appreciated by residents, until they are directly affected by the process. This process, which is visible, is sometimes imperceptible to nearby residents, or faintly appreciated by them. Based on the interviews conducted, all the farmers were aware of the presence of urban expansion. Most of the respondents said that they noticed some of their farmlands 
being surrounded by houses and other forms of construction going on but could not place a finger as to what it could be called or what they were to expect until much later. One male respondent said, "... it was difficult for me to realize from the beginning the presence of urban expansion because it was not as obvious then as it is now".

However, with the intensification of its impact on the livelihood of not only farmers, most of the farmers are now becoming aware of the situation. According to one of the respondents in Bamenda II, he hardly noticed these changes as a young man when his father's farmland was taken by the government for the construction of an airport. Until the time of the interview, there had been no compensation. To him, just this incident alone did not create an awareness of urban expansion. Until two other parcels of his land were encroached upon and one completely taken over by his cousin for construction, then he realized that expansion was taking place.

A similar situation was observed for the Nkwen-Bambui axis (Bamenda III) where very few of the interviewees were already aware of the phenomenon and its evidence even before they were hit. Thus, few interviewees expected it even without knowing the gravity of its occurrence while most of those interviewed did not. Some respondents intimated that it was their craving to have their neighborhood which was sparsely populated in the past to be developed. They, however, did not consider the flipside of this development (deprivation of farmlands), until the situation became acute. Those who were not aware of the situation at all were more affected than those who had an idea it will occur and possibly took precautionary measures. Another female respondent said:

I had friends that had been affected in one way or the other, but I really did not think it could come with strong implications not until I was faced with it. It was a nice thing for me to realize how development was being brought to us gradually through what you call urban expansion. Honestly, I never imagined that there was another side to it probably because I was not touched. I know roads and shops that were opened as more houses and offices were built in my area because of expansion of the city which was and still is a good thing.

\subsection{Livelihoods Repertoire and Portfolio of Farmers before Urban Expansion}

To further explore the effects, an analysis of the livelihood repertoire and portfolio of farmers was conducted. Livelihood repertoire in this case includes the livelihood capabilities and activities while portfolio includes a farmer's assets and income.

\section{(a) Activities}

Even though the main activity is farming, not all farmers relied on it. In both case studies, two of the affected respondents had farming as a secondary activity while their primary activities were teaching and commerce. All the other respondents had farming as their main activity which they carried out about four times a week on average between Monday and Saturday. Sunday was considered a non-farming day by all respondents. In addition to Sundays, the farmers were left with at least a day or two off their farms per week. These two days are traditionally declared non-farming days which are rotatory each week. Not all the farmers strictly respect these "traditional Sundays" as they are called.

How much attention I gave to my farm? (Laughs). How can you ask a full-time farmer that? If I was not on the farm where else would I be? I did not even respect our traditional Sundays and that is how bad my own case was. Apart from Sunday which was my official off-farm-day, I was always on the farm. I only reduce farm going when my crops are at a stage where they do not need much attention. But it is so difficult not to find something to do on the farm.

Meanwhile, those who do not go to their farms on these days are engaged in other secondary income-generating activities such as commercial bike riding, sales of farm output, and their engagement in domestic work for other households. This is what a female respondent had to say, "I went to the farm 
except on Sundays and other traditional Sundays it is so annoying to respect traditional non-working days though I do it anyways. I use those days to either attend reunions, rest, or just have family time."

As for the full-time teacher and businesswoman/trader, they both respected the non-farming days of the week. They spent an average of two days per week on their farms. Even though most of their considered working days were not all full days, they were still satisfied with the attention they gave to their farms and with the returns they got. One said, "I went to my farm whenever I could especially during my considered free days or sometimes after school, I just tried to do enough not to let my little effort be put to waste."

\section{(b) Sources of Income}

The main source of income for respondents prior to urban expansion came from the sale of farm output. Most of the cultivation done especially given the vast cultivated land was for commercial purposes although some of the crops grown were equally consumed in a bid to reduce the family's expenditure on feeding. Some farmers during a focus group discussion session said they also depended on incomes from family members out of Bamenda, be they at home or abroad. Most of the support did not come as an obligation but rather assistance. With regards to this, the following were noted. "I often times got support from siblings for specified purposes like health issues payment of school fees amongst others this was done only when I could show proof of my claims or make them believe that what I was claiming was real or true," said one female respondent.

... It is not only farming that puts food on my table or takes care of my family. ... I am not saying that only farming is too menial for me to have achieved a good life, but I was lucky too to have some support from my brother abroad. He sent me money from time to time based on errands I ran for him back home. - Male respondent

Can I consider sponsorship and scholarship as part of income because my son earned a community scholarship that paid his fees every year also my last two children were sent to school every year by my sister's husband? He sent money for their school fees and all other school needs every year. - Female respondent

In my own case I am or was not the only one that brought income to the family my wife also assisted a great deal. She did petit trading making snacks and selling them on campuses during lunch time and she was also a domestic servant for three families. - Male respondent

Respondents in both study sites noted that they relied mostly on the kind of crops they produce and spend very little on what they do not cultivate. This means that if a family cultivates mostly maize and beans, then most of their meals will be centered around these two crops, reducing the spending on other non-cultivated crops like rice. There are also secondary sources of income gotten from secondary activities such as teaching and domestic maids for inhabitants in the Nkwen-Bambui axis and working on other people's farms for payment in the Mankon-Bafut area. These other sources of income equally assist in household expenditures such as the payment of school fees and other bills. In addition, others got aid in terms of support from other family members.

\section{(c) Assets}

Before urban expansion became pronounced, land was the main asset for some informants. They equally owned other properties such as cars and houses. Almost all the respondents had no burden of paying house rents. This was largely because some of the property like the land and houses they possessed were inherited from parents and other family members. Some also lived in and occupied houses and land owned by friends and other family members. The only conditions attached to their stay and occupation of the property was that they should secure it. The wealthy class who owned some of the land and houses were generally not living in Bamenda-some of them lived in other cities and abroad. Their absence caused their property to be attractive for other inhabitants 
with expansionist urges. To safeguard the property, they assigned it to some of these farmers who control and use them to discourage any claims of ownership by other parties over the land or house. A respondent (female) and a few informants at the focus group discussions considered the free labor they got from members of their household as an asset worth mentioning. They had this to say:

I had a large family then and they were really very supportive with very little exceptions. ... There wasn't any specific age for them to go or not go to the farm because we carry the very little ones to the farm as well and keep them under a tree for shade meanwhile, we work. When they eventually start walking, they try to do one of two things on the farm and we do not stop them in most cases and that is how they start embracing farming. Generally, they were all resourceful.

\section{(d) Family Size}

Family sizes were mostly large, ranging from about 5 to $16+$ members per household. The situation was common in most parts of the West and North-West Regions of Cameroon where the quest for social recognition and to have a steady supply of household labor prompted most families to be large. Even though the family sizes were large, the farmers could support this, and they could still cater for such families, even if with some difficulties and challenges. Most of the farmers believed that having more children meant an increase in the labor force which will of course increase agricultural output. This archaic mentality had been very common to farmers around the fringes of Bamenda.

\section{(e) Farm Size and Type}

Since prior to urban expansion, there were relatively significant portions of land for farming; it was evident that farmers in both study areas at the time had the opportunity to expand their farms. In other words, the availability of land before expansion made it possible for farmers to own large farm sizes. This was further supported by the fact that they had large family sizes to serve as a source of labor supply for the large farms. During this period, farm sizes ranged between an average of 200 and $500 \mathrm{~m}^{2}$ for the Mankon-Bafut axis and between 300 and $800 \mathrm{~m}^{2}$ for the Nkwen-Bambui axis. In this regard, most farmers had at least three or more plots of land although with varied farm sizes. This explains why they needed "cheap or free" labor to be able to take care of the farms. In most cases, the number of plots of land cultivated was determined by the manpower since they had access to other pieces of land. This meant that with an increase in household sizes which led to an automatic increase in labor supply, they could obtain new pieces of land for cultivation since there was available labor supply. This just shows the extent to which land was readily available at that time.

Concerning the type of agricultural practices carried out, most farmers practiced shifting cultivation. This could be explained by the availability of land. The trend taken or used by most farmers was to cultivate a piece of land for two or three years and let it fallow for a year or two. The duration of fallow depended on the number of pieces of land they have access to. Fallow periods ranged from one to two years in the Nkwen-Bambui axis as against two to three years in the Mankon-Bafut axis. Such plots of cultivated land were partitioned into sections where different crop types were planted. This means that a farm consisting of about three or four columns equally had three or four different crops planted on each of the columns. Amongst the crops cultivated were maize, beans, yams, cocoyam, potatoes, groundnuts, and soybeans. The farmers decided which farmland would carry specific crops based on the yields from the specific crop on particular farmland. Usually, each crop was cultivated where it was believed to have maximum output or yields. At this period, farmers had available seed varieties to be able to cover all the land cultivated and the option of farm intensification was not taken into consideration.

Another important aspect had to do with the average distances covered to get to the farm. Prior to urban expansion and due to the availability of land, most farmers could cover between 100 and $300 \mathrm{~m}$ in the Nkwen-Bambui axis and 200 to $500 \mathrm{~m}$ in the Mankon-Bafut area to get to their farms. This is an indication that the farms were relatively close to their homes in both case studies. 
Most farmers initially did not worry about expansion before they started noticing its evidence. They lived a very stable life without any notion or thought of what could happen in the near future to their farmlands. During this period, the main issue they were worried about concerning their activities was climate variability and change and their effects on crops in terms of earlier or later than expected rainfall and less than or more than expected rainfall and sunshine, among others. Farmers in both study areas were equally worried about farm input quality (seeds), pests and diseases, and the issue of theft of farm output, including transportation, storage, and marketing of food crops. None of the respondents indicated that it was an issue or a burden to take care of many children during this period because of food abundance. At this time, they saw large family sizes as assets because they could squeeze out labor from them. Every child of school-going age was attending school; school fees were paid whether on time or not, depending on the family; and basic needs for the family were being met. In some cases, households compensated for fees by supplying food items worth the fee amount in some boarding schools. In addition, some considerable amount of money was available for savings. A male respondent from the Nkwen-Bambui axis explained in the following words:

I would not say I was living in affluence then but what I got was sufficient for myself and my family... you can always say you are rich financially when you can afford comfortably the basic necessities of life. I equally was not living a hand to mouth life because money gotten from the sale of farm output could provide even for my saving. I mean it actually made up part of what I saved each month.

This idea was equally shared by majority of the respondents who said they considered or could rate their living condition as very comfortable. There was only one exception to this idea as the respondent said, "... I cannot actually tell you I was 100\% fine because I still lived in debts back then, even though the situation is worse now."

\subsection{Livelihood Repertoire and Portfolio after Expansion}

Urban expansion led to a change in the livelihood repertoire and portfolio of farmers as explained below. Although the effects were largely similar, some peculiarities exist for the Mankon-Bafut and the Nkwen-Bambui axes.

\section{(a) Activities}

Unlike the period prior to expansion, where farming was the primary activity, the situation changed after expansion. Farming, which used to serve as the main economic activity for most farmers, lost its place in the study area as exemplified by a reduction in the number of farms and farm sizes. The views of two informants during the focus group discussions were:

... and there is a lot of time on my hands now but nothing much to do I was so used to always going to the farm but now I do petit trading, that is, buying things from the city and selling them in interior markets on their market days which take place one a week. —one informant

Even though it does not add up to my income directly I can say that I was one person who was never regular at meeting sessions no had the time to participate in activities of the community but now that I have only one small farm, I am more active and dedicated. 一one informant

Farm size reduction was registered in favor of settlement expansion. Consequently, farmers have now opted for intensive agricultural activities and mixed cropping wherein much emphasis is placed on the limited land available to maximize output from the farms. The situation was more labor-intensive where the available workforce supersedes the resources or farm sizes. Hence, there has been an increase in the number of days set aside for non-farming activities-the initial one or two days of rest set aside each week increased to four or more days averagely dedicated to non-farm activities. 


\section{(b) Sources of Income}

Due to a reduction in farm sizes, there was a reduction in crop output, and this has affected the income levels from farming of farmers negatively. Agricultural output became very unreliable and so it was no longer considered as a dependable source of income. This led to a shift in the role of income sources with secondary sources of income now playing the primary role. In clear terms, hitherto secondary sources of income such as part-time teaching, bike riding, and commerce, which were common amongst respondents in the Nkwen-Bambui area, and domestic work as well as buying and selling other non-farm products/items (common in the Mankon-Bafut axis) assumed the role of primary income sources.

... Yes of course if one loses his land and does not have where to farm, he must try to find an alternative means or activity to earn money. Alternatively, for me, I engaged in commercial motorbike riding during the weekends from Friday to Sunday I rent a bike and transport people. I learned how to ride a bike just as I was trying to find myself out of the challenges, I faced hopefully I can get my own bike one day. -Male respondent

Faced with the difficult economic situation for farmers, farmers have sought to borrow, and this situation has increased when compared to the previous situation. Worse still, the prospects of re-paying are slim because of their virtual loss in economic opportunities. Agriculture and the sale of the farm outputs now assume a secondary role as an income source for households. However, this was the case for most or all farmers whose lands were lost without any sort of compensation or those who received meager compensation. It was much more pronounced in the Mankon-Bafut axis.

It is very difficult for me to have coped without borrowing. At the beginning of every academic year I borrow money from a microfinance and spread payment within the year and if I have other commitments which come up, I borrow from family or friends (usually it is a small amount of money compared to what I take from the bank). Presently the yearly loan that I took from the bank I have stopped that because my business is growing fast and right now, I have grown past borrowing meagre amount I used to. - Male respondent

The few people who were compensated, regardless of whether or not they were satisfied with the compensation, acquired farming land elsewhere or diverted the income and invested in other economic activities, especially trading and motorbike riding. Farmers in the Mankon-Bafut axis drifted in their search for farmlands to villages in Bafut while those of the Nkwen-Bambui axis now have farms along the Babanki-Kom highway and in the Ndop plains. They, however, complained that the newly acquired farmlands were small, not easily accessible in terms of distance, and, above all, less fertile than their previous farms. This still results in very lean incomes realized from the sale of the reduced farm products from such farms. A farmer in Mankon explained that the compensation had nothing positive to do with his source of income subsequently. This was because the money was offered to him some twelve years after his land was colonized, after several court proceedings which were financially demanding. More generally, after urban expansion, there was a strain on the income sources of the families.

\section{(c) Assets}

Due to urban expansion, the main assets of these farmers (land) either changed ownership or they were encroached upon. At the moment, farmers in the study area, therefore, have very little or no land possession at all. Land availability became very scarce to the farmers and they either have very little of their land to hang on to or nothing at all. This is because some families had a complete loss of their farmland while others lost only part of it.

... It is very difficult for me to evaluate what assets I have because I have finally lost all of my cultivable land. But there are two things I can say I hang onto now which are my house 
(where I pay no rents) and my children or should I say family. When I say my family, I specifically refer to the strong and healthy who can do odd jobs to fend for the rest of the family... so, they are my assets. - Female respondent

This was just a more elaborate response of how or the point of view of other respondents. They said they considered anything which does not strain them financially as an asset.

\section{(d) Family Size}

More commonly, family sizes reduced. Large families that were believed to be a source of labor for the farms were now regarded as liabilities. The burden of feeding many mouths and caring for many people became heavy. Some of the family members that came from other relatives were sent back to their original families. Some children were sent to live with other households and serve as housemaids. All these were meant to reduce the burden on the available family budget thereby decreasing family sizes.

... I had no option but to send five of my children to other relatives and family friends. I really do not regret this because they were the same people, I assisted at one point in life when I could. So, I do not think they took offence with this. At least none that I can think of right now. - Female respondent

\section{(e) Farming Type and Farm Sizes}

The partial or complete takeover of farmers' farmlands meant an automatic decrease in the available agricultural land. Farm sizes were not only reduced but the total number of pieces of land cultivated became very few. This, therefore, means that some of the farmlands completely transformed into buildup areas while others were only partially affected. Smaller farm sizes and fewer cultivable land affected the farming practices of farmers. Instead of shifting cultivation as before, farmers now practiced intensive farming. Some of the farmers said they adopted the "urban agricultural" form of agriculture. They used car tires or bags, filled them with soil, placed them around the house, and planted crops in them. The focus was on the cultivation of vegetables and tubers which were meant for home consumption with very little being sold to make available other basic products that they cannot cultivate on their farms.

It is important to note here that not all the crops formerly produced by the farmers were still produced after expansion. This is just because of the mixed cropping which they practiced wherein the farm sizes could not accommodate all the crops they cultivated before. In another dimension, since most of the nearby farms were colonized by settlements, the average distances covered by farmers to get to their farms increased tremendously. Farming distances have moved from 100 to $300 \mathrm{~m}$ to 1 to $2 \mathrm{~km}$ in the Mankon-Bafut axis and from 200 to $500 \mathrm{~m}$ to 2 to $4 \mathrm{~km}$ in the Nkwen-Bambui axis. Most of the farmers in both study sites covered at least above $1 \mathrm{~km}$ to get to their farms. Some farmers even went beyond the fringes of Bamenda to nearby villages such as Bali and Bafut for those in the Mankon area, and Sabga, Ndop, Santa, and Akum for those in the Nkwen area.

There was a clear contrast in the livelihood situation of farmers before and after expansion. Some farmers described their current situation as "hopeless", not only because of the "tragic" events (involving the loss of land and main source of livelihood) affecting them but also because most of the alternative livelihood measures they turn to could not totally support their livelihood activities. This was the period when most of the farmers interviewed hardly met their basic needs. Children's education came to a halt as parents could not afford the fees. This made some of the children become wayward, increasing insecurity in the area. The dependency ratio increased as some of the farmers had to depend on other family members for livelihood. All the farmers, including those who had farming as a secondary source of income, had a very bitter experience after expansion. The gravity of the effect depended mostly on the household characteristics such as family size, degree of dependence on farming, level of social ties, age of children, and possibilities for income diversification, among others. 
The positive side was that it brought to the farmers' awareness the prevalence of such a situation or circumstance. Most farmers developed a resistance against such occurrences and learned the necessity of diversification of sources of income.

\section{Discussion}

Very significant changes were observed as far as urban expansion in Bamenda is concerned. With the increasing human population and the demand for space, the process of urban expansion accelerated between 2000 and 2015 with significant indicators. In Bamenda II, for instance, there was a reduction in the surface area for farmlands from 3540 ha to 2100 ha and a corresponding increase in the surface area for settlements from 2100 ha to 3540 ha. In a similar manner, there was a reduction in the surface area for farmlands from 2943 ha to 1389 ha and a corresponding increase in the surface area for settlements from 1389 ha to 2943 ha between 2000 and 2015 for Bamenda III. The general practice was shifting cultivation with fallowing periods ranging between 2 to 3 years. Today, focus is on mixed cropping where one ridge constructed carries about four different crop types and there has been a reduction in fallow periods. This is opposed to the situation before where it would carry only one crop type.

Prior to urban expansion and due to the availability of land, most farmers could cover between 100 and $300 \mathrm{~m}$ in the Nkwen-Bambui axis and 200 to $500 \mathrm{~m}$ in the Mankon-Bafut area to get to their farms. After expansion, farming distances increased from 100 to $300 \mathrm{~m}$ to 1 to $2 \mathrm{~km}$ in the Mankon-Bafut axis and from 200 to $500 \mathrm{~m}$ to 2 to $4 \mathrm{k} \mathrm{m}$ in the Nkwen-Bambui axis. Based on the farmers' explanations of what they could do with their income then and what they do now (at the time of the research), it was observed that incomes reduced approximately between $40 \%$ to $60 \%$ for the Mankon-Bafut axis and $50 \%$ to $80 \%$ for the Nkwen-Bambui axis.

Given the situation in Bamenda city, it is obvious that urban expansion had a significant increase over the years. This ties with most of the literature which confirms the continuous increase in both developed and developing countries. The city of Bamenda has interestingly had sprawl in different patterns. At the early or almost initial stage the most common form of expansion was vertical expansion a period where some house/landowners demolished their buildings to construct story buildings and newest buildings at that time were constructed using solid foundations for story buildings even if they will not to be completed immediately. Then the suburban expansion started where mostly the rich people moved away from the city centers to peripheries where it is spacious and quiet. This was possible as they could afford private transportation. With the current or recent improvement in public transportation systems in Bamenda city, it is now possible for people to conveniently stay away from the city center and commute to the city center when desired. Thus, visible peri-urban areas with unofficial patterns of land use. This is the common trend in Bamenda's expansion.

As the world population keeps on growing the quest for land keeps on rising and the trend in urban expansion keeps changing; urban expansion is experienced differently at different periods and within different places. Generally, world trends have indicated there is an increase in urban expansion all over the world but the reasons for and type of expansion are respective to various places. According to the UN, in reference [8], the total population of the world that lives in urban areas exceeds the rural figures and its projections by 2050 is that $70 \%$ of world population will live in urban areas while $86 \%$ will come from OECD countries. Meanwhile, as other places experience more vertical expansion, some rather experience more of horizontal expansion. In some cities, the nature of expansion is different from others in that they have large peri-urban areas with informal or illegal land use patterns and others experience suburban sprawl. The results equally tally with reference [24] who observed that urban expansion in the United States claimed more than 1 million acres per year between 1960 and 1990. Yet, it is not seen as a threat to most farming, although it may reduce production of some high-value or specialty crops. The consequences of continued large-lot development may be less sanguine, since it consumes much more land per unit of housing than the typical suburb.

Although all farmers interviewed were aware of the process of urban expansion, their perceptions towards it varied. Most of the farmers interviewed were already aware in one way or the other of the 
prevalence of urban expansion. Before expansion (especially those who were not very aware of the trend of urban expansion), the way of life of farmers was different from after expansion. Their activities changed as some changed their then secondary source of income to now primary source of income. Farm sizes reduced as well as productivity, partly because of low inputs and change in farming type as a means of adaptation. Before expansion, managing large family sizes was not a point of worry to most interviewees, since they believe that the more the labor the more the productivity and more income, too. After expansion, large families were burdensome because it became difficult to feed and provide for all basic needs. The process equally affected the livelihood repertoire and portfolio with respect to farm sizes and practices. Prior to the year 2000, farm sizes ranged between an average of $200 \mathrm{~m}^{2}$ and $500 \mathrm{~m}^{2}$ for the Mankon-Bafut axis and between $300 \mathrm{~m}^{2}$ and $800 \mathrm{~m}^{2}$ for the Nkwen-Bambui axis. It agrees with reference [25] who analyzed changes in farm sizes covering 21 regions in eight African countries for the period between 2002 and 2008. Their results showed that there has been a declining trend in farm size except for Nigeria where farms grew substantially over the six years; farm sizes have either remained stable or declined. The study equally revealed that the per capita access to farms was down to 0.12 ha or less for the $25 \%$ smallest farms, except for Ethiopia and Nigeria. In Kenya, the lowest quartile only had 0.04 ha per capita.

There are several impacts on urban expansion which may be positive or negative, ranging from economic, social, political, and otherwise. This is equally the case in Bamenda as some farmers either lost all or part of their land, witnessed a decrease in productivity due to displaced animals and source manure, and faced difficulties in some coping strategies especially in the initial phase of it. That notwithstanding, most of the writers or authors failed to acknowledge how beneficial urban expansion was or has been to some of the peri-urban farmers. Hence, the positive side of urban expansion on peri-urban farmers was neglected. However, in as much as most of the farmers in Bamenda faced or are still facing the negative effects of urbanization, other farmers confessed that the process of urban expansion positively changed and improved on their livelihoods. Some achieve education which has placed them in better ranking positions while others switched to more profitable livelihood alternatives and urban integration became easier. In general, welcoming development in most of its forms contribute to urban expansion improves livelihoods and eases life. In the literature, reference [26] acknowledges that the livelihood elements and strategies of peri-urban farmers are greatly affected through a decrease in farm sizes, the displacement of farmers, and changes in their livelihood strategies amongst others. These are some of the points put forward by other writers.

In Bamenda, land grabbing is common and most poor farmers or small-scale farmers are more vulnerable because they do not have the ability to defend themselves due to their poor status. In the case where the law is applicable to the favor of the farmers, some of them attest to corruption, manipulation, and marginalization from the forces of law and order. Hence, it is safe to over-emphasize the rule of the government and local authorities in ensuring the farmers' satisfaction. There is no need to over-emphasize the issue of corruption in most African countries (Cameroon being one of the top-ranking) and how unfair the practice is to most citizens. The same situation is prevalent in China, where an estimate of about 50 million rural people lost their land due to rapid urban expansion, caused by industrialization [27]. This placed much pressure on the peasants at that time, given that China had no social security system covering farmers in rural areas. More so, most of these farmers did not receive any sort of compensation [28]. Therefore, consideration needs to be given for the introduction of an effective social security systems for farmers. In Bamenda, farmers are directly impacted through loss of assets and source of income. Production and productivity are equally affected, and these situations pose a challenge to the farmers. Although not all the farmers are still suffering the effects of expansion until present day, they all could attest to a difficult initial period (the period when they just lost their land).

Most of the farmers were already aware in one way or the other of the prevalence of urban expansion. The way of life of farmers was different after expansion. Their activities changed as some changed their then secondary source of income to now the primary source of income. Farm sizes 
reduced as well as productivity, partly because of low inputs and change in farming type as a means of adaptation. Before expansion, managing large family sizes was not a point of worry to most farmers since they believe that the more the labor the more the productivity and more income, too. After expansion, large families were burdensome because it became difficult to feed and provide for all basic needs. The mentality that some farmers had about urban expansion was that it is bad; this is especially true for the less educated. To one of the male respondents,

... urban expansion is evil and just a way to manipulate and marginalize the under privileged. You cannot disagree with me totally because I have had no visible good thing come out of all this. My farmland was taken away and I was promised compensation, but nothing has been given to me and it about 9 years today. My children left school and we sold almost all our property but ventured into the wrong business because I am not used to such investments. Most of you should know by now the reason why I lost my youngest son to hunger and malnutrition and my wife left me for another man because I could not provide for her anymore. I honestly did not have a name for all these until now that you can tell me it called urban expansion.

This does not rule out the fact that some farmers are happy for the fact that this came to them as a breakthrough. They left farming for more lucrative jobs. One of the focus group participants said:

Yes, I received compensation for my land, and I am very grateful for that because some other women until today have not been paid even a little portion of the money. I was devastated at first but when I received the money, in two instalments, it was in time when I needed it. I had an opportunity to get a place into a professional school and the only issue was money. I sort for help for months and got nothing favorable and just when I was about to give up, I received a call that my name was amongst those to collect their money. So, I am now a teacher with the government, and I am assured of my monthly income and I can continue with farming because I have enough time. Had this not happened to me, I am sure I will not be able to get even a quarter of what I was expected to bring, or I will probably remain a farmer. ... of course, I cannot compare my net income now to when I was a farmer. (Laughs) they are worlds apart.

Subsequent challenges depended on how fast the farmer was able to accept the changes, how sustainable the degree of efficiency of survival strategies which were implemented, or other related individual situations. All these contributed in determining the stability in the farmers' quest to restore or improve their livelihood after expansion. According to reference [24], between the years 1960 to 1990, urban expansion claimed more than 1 million acres of land per year and did not pose a threat to most farmers, although maybe the production of some high-value crops did increase some competition. This is directly the reverse of what is happening in Bamenda today. The results may differ maybe based on the availability of land or the period in which the research was done or even disparities in the developed and developing societies.

\section{Conclusions}

Urban expansion is an ongoing phenomenon that requires careful scientific and policy reflections. This concerns Bamenda, our case study. The aim of the paper was to explore the dynamics of urban expansion and its role in shaping the livelihoods repertoire and portfolio of farmers. We concluded here that in both cases, a significant reduction in the size of farmlands have been registered as urban expansion manifested through settlement construction. The expansion process has affected farmers' income, farm sizes and farming types, natural capita, and their standards of living. Most of the farmers have employed coping measures to include the diversification of income opportunities, social networking, agricultural intensification, and borrowing, among others. Much effort are required to seek permanent solutions to the effects of urban expansion. Traditional authorities, government 
officials, non-governmental organizations, and farming group networks have attempted in one way or the other to address the issues related to urban expansion especially as it affected farmers at the peripheries. Future efforts could target land use regulations to stem the uncontrolled rate of settlement expansion, intensive farming to increase productivity, and processing to improve the value chain in a bid to increase income levels and provide long-term food self-sufficiency. This paper suggests further quantitative investigations to ground the current assertion.

Author Contributions: Conceptualization, investigation, writing—original draft, A.S.G. and writing—review and editing, J.N.K. All authors have read and agreed to the published version of the manuscript.

Funding: This research was funded within the framework of the Norwegian Government Quota Scholarship scheme 2014-2017. The APC was provided by the Sächsische Landesbibliothek - Staats- und Universitätsbibliothek (SLUB) Dresden.

Conflicts of Interest: The authors declare no conflict of interest.

\section{References}

1. Muluken, D. An Assessment of the Impact of Urbanization on Peripheral Community Livelihood: Akaki kality Sub-City Case. Master's Thesis, Ethiopian Civil Service College, Addis Ababa, Ethiopia, 2009.

2. UN-Habitat. Harmonious Cities: State of the World's Cities 2008/2009; UN-Habitat: London, UK, 2009; Available online: www.clc.org.sg/pdf/UN-HABITAT20Report\%20 (accessed on 30 August 2009).

3. Araya, Y.H. Urban Land Use Change Analysis and Modelling: A Case Study of Setubal-Sesimbra, Portugal. Ph.D. Thesis, NOVA University, Lisbon, Portugal, 2009.

4. Allen, A.; da Silva, N.; Corubolo, E. Environmental Problems and Opportunities of the Peri-Urban. Interface and Their Impact Upon the Poor; Development Planning Unit, UCL: London, UK, 2009.

5. Bryant, C.R.; Russwurm, L.H.; McLellan, A.G. The City's Countryside: Land and its Management in the Rural-Urban Fringe; Longman: London, UK, 1982.

6. Ilbery, B.W. Agricultural specialization and farmer decision making in the West Midlands. Tijdschr. voor Econ. Soc. Geogr. 1984, 75, 329-334. [CrossRef]

7. Kimengsi, J.N.; Gwan, S.A.; Elinge, L.E. Peri-Urban Settlement Dynamics in BUEA, Cameroon: Planning Challenges. UGEC Viewpoints: A Blog on Urbanization and Global Environmental Change. 2016. Available online: https://ugecviewpoints.wordpress.com (accessed on 10 November 2018).

8. Organzation for Economic Cooperation. OECD Trends in Urbanisation and Urban Policies in OECD Countries: What Lessons for China? 2010. Available online: https://www.oecd.org/urban/roundtable/45159707.pdf (accessed on 11 January 2017).

9. Bentinck, J. Unruly Urbanization on Delhi's Fringe: Changing Patterns of Land Use and Livelihood. Utrecht/Groningen; The Netherlands Geographical Studies: Utrecht, The Netherlands, 2000.

10. Kimengsi, J.N.; Nguh, B.S.; Nafoin, A.S. Peri-urban land use dynamics and development implications in the bamenda III municipality of Cameroon. Sustain. Environ. 2017, 2, 273-288. [CrossRef]

11. Kimengsi, J.N.; Fogwe, Z.N. Urban green development planning opportunities and challenges in sub-saharan Africa: Lessons from Bamenda city, Cameroon. Int. J. Glob. Sustain. 2017, 1, 1-17. [CrossRef]

12. Balgah, S.N. Population growth and land use dynamics in Buea urban area, Cameroon. Loyola J. Soc. Sci. 2007, 17-31.

13. Amawa, S.G.; Kimengsi, J.N. Accelerated Urbanisation in the Buea Municipality: The Question of Sustainability in the Provision of Social Services. In Proceedings of the International Conference on Sustainable Cities, Cameroon, Yaounde, 10-13 November 2009.

14. Nyambod, E.M. Environmental consequences of rapid urbanisation: Bamenda city, Cameroon. J. Environ. Prot. 2010, 1, 15-23. [CrossRef]

15. Kometa, S.S.; Akoh, N.R. The hydro-geomorphological implications of urbanisation in Bamenda, Cameroon. J. Sustain. Dev. 2012, 5. [CrossRef]

16. Balgah, S.N.; Kimengsi, J.N. Land use dynamics and wetland management in Bamenda: Urban development policy implications. J. Sustain. Dev. 2016, 9, 1-11. [CrossRef]

17. Balgah, R.A.; Kimengsi, J.N. Can policy deviance reduce poverty? Empirical evidence from self-return environmental migrants in Cameroon. Soc. Sci. J. 2019, 69, 87-103. 
18. Kimengsi, J.N.; Mukong, A.K.; Balgah, R.A. Livelihood diversification and household well-being: Insights and policy implications for forest-based communities in Cameroon. Soc. Nat. Resour. 2020, 1-20. [CrossRef]

19. DFID. Framework Introduction. Sustainable Livelihoods Guidance Sheets. 2000. Available online: http://www.eldis.org/go/topics/dossiers/livelihoods-connect/what-are-livelihoods-approaches/ training-and-learningmaterials (accessed on 8 September 2016).

20. Saldaña, J. The Coding Manual for Qualitative Researchers, 2nd ed.; Sage Publications: Thousand Oaks, CA, USA, 2013.

21. Tellis, W. Introduction to case study. Qual. Res. 1997, 3, 269.

22. Bowen, G.A. Naturalistic inquiry and the saturation concept: A research note. Qual. Res. 2008, 8, $137-152$. [CrossRef]

23. Woiceshyn, J.; Daellenbach, U. Evaluating inductive vs deductive research in management studies. Qual. Res. Organ. Manag. Int. J. 2018, 13, 183-195. [CrossRef]

24. Heimlich, R.E.; Anderson, W.D. Development at the Urban Fringe and Beyond: Impacts on Agriculture and Rural Land; Agricultural Economic Report No. 803; Economic Research Service, U.S. Department of Agriculture: Washington DC, 2009; pp. 5-88.

25. Andersson, A.; Djurfeldt, G. African smallholders-food crops, markets and technology. In Maize Remittances, Market Participation and Consumption Among Smallholders in Africa; Djurfeldt, G., Aryeetey, E., Isinika, A.C., Eds.; CABI Publishing: Oxford, UK, 2010.

26. Bekele, F. The Impact of Horizontal Urban Expansion on Sub-Urban Agricultural Community Livelihood: The Case of Tabor Sub-City, Hawassa City, SNNPRS, Ethiopia; Institute of Rural Development, College of Development Studies, School of Graduate Studies Addis Ababa University: Addis Ababa, 2010.

27. Zhao, Y.; Li, X.; Xin, L.; Hao, H. Geographic concentration and driving forces of agricultural land use in China. Front. Earth Sci. 2012, 6, 48-56. [CrossRef]

28. Keliang, Z.; Prosterman, R. Securing land rights for Chinese farmers: A leap forward for stability and growth. Cato Dev. Policy Anal. Ser. 2007, 3, 20.

(C) 2020 by the authors. Licensee MDPI, Basel, Switzerland. This article is an open access article distributed under the terms and conditions of the Creative Commons Attribution (CC BY) license (http://creativecommons.org/licenses/by/4.0/). 